\title{
Grape Pruning Stem Extract (GPSE) Suppresses Allergy and Skin Proliferation Inhibition against UVB Induced Skin Damage
}

\author{
Joung-Hee Kim ${ }^{1}$, Dae Hwan Kim², Keuk-Jun Kim ${ }^{1}$ \\ ${ }^{1}$ Department of Biomedical Laboratory Science, Daekyeung University, Gyeongsan, Korea \\ ${ }^{2}$ Department of Laboratory Animal Research Support Team, Yeungnam University Medical Center, Daegu, Korea
}

\section{포도전정가지 추출물이 UVB에 유도된 피부 손상에 대한 알레르기와 피부증식 억제효과}

\author{
김정희 ${ }^{1}$, 김대환 $^{2}$, 김극준 $^{1}$ \\ ${ }^{1}$ 대경대학교 임상병리과, ${ }^{2}$ 영남대학교의료원 연구지원팀 실험동물실
}

\begin{abstract}
This study examined the effects of polyphenols in grape pruning stem extracts (GPSE) using grape stems discarded after harvest. The inhibitory effects on allergy, proliferation, and apoptosis in UVB-induced HR-1 hairless mice were analyzed. The applicability as a material for functional food and functional cosmetics was evaluated. The contents of the active ingredients of GPSE were analyzed by HPLC. After UVB irradiation on the dermis of HR-1 hairless mice, the number of mast cells was determined by toluidine blue staining to confirm that the skin allergic reaction was caused by GPSE. The results were similar to the normal group in the group applied GPSE, and there was no allergic reaction in the GPSE application group and a significant decreased compared to the sun cream control. PCNA immunohistochemical staining of the epidermal proliferation factor had an inhibitory effect on epidermal epithelial cell proliferation in all concentrations of GPSE and serum base mixture as an average of $42 \%$ compared to the control group. The mixture of GPSE and serum base suppressed the apoptosis inhibition rate by $27 \%$ on average compared to the control. These results confirmed the inhibitory effects GPSE on the allergic, proliferation, and apoptosis activities by with a serum base on UVB-induced skin damage. GPSE is a functional ingredient with potential skin protection effects, and has a high utilization as an ingredient for functional cosmetics.
\end{abstract}

Key words: Anti-allergic, Anti-apoptosis, Anti-proliferation, Grape pruning stem, UVB

This is an Open Access article distributed under the terms of the Creative Commons Attribution Non-Commercial License (http://creativecommons.org/licenses/by-nc/4.0) which permits unrestricted non-commercial use, distribution, and reproduction in any medium, provided the original work is properly cited.

Copyright $(2017$ The Korean Society for Clinical Laboratory Science. All rights reserved.
Corresponding author: Keuk-Jun Kim Department of Biomedical Laboratory Science, Daekyeung University, 65 Danbuk 1-gil, Jain-myeon, Gyeongsan 38547, Korea Tel: 82-53-850-1266 Fax: 82-53-850-1496 E-mail: biomed@tk.ac.kr

Received: October 15, 2017 Revised $1^{\text {st: }}$ October 30, 2017 Revised $2^{\text {nd }}$ : October 30, 2017 Revised 3 ${ }^{\text {rd }}$ : November 22, 2017 Revised 4 ${ }^{\text {th}}$ : November 23, 2017 Revised $5^{\text {th }}:$ November 27, 2017 Accepted: November 27, 2017

\section{서 론}

포도는 미국종(Vitis labrusca L.), 유럽종(Vitis vinifera L.) 및 이들 상호간의 교잡종(Vitis labruscana L.) 등 3종으로 크게
나눌 수 있고[1], 유럽과 서아시아에서 재배되다가 1909년에 캠벨얼리 품종이 우리나라에 도입되 환경에 가장 잘 적응하여 지금까지도 주 재배품종으로 재배되고 있다[2]. 국내에서 육성 된 포도품종과 현재 우리나라에서 많이 재배되고 있는 캠벨얼 
리, Muscat Bailey A (MBA) 품종의 부위별 주요 폴리페놀 화합 물의 함량을 분석하여 다양한 포도 가공품의 개발 및 이용을 위 한 자료도 보고되고 있다. 전체 포도 품종의 부위별 함량 비교에 서는 전반적으로 송이줄기에서 가장 높은 함량을 나타내었고, 과육에서 가장 낮은 함량을 나타내었다. 따라서, 품종 또는 부위 에 따라 함량의 차이가 큰 것으로 보고되었다[2,3]. 포도는 폴리 페놀 성분이 풍부하여 여러 가지 생체조절 기능을 나타낸다고 알려져 있다. 폴리페놀 성분 중 플라보노이드 화합물(flavonoid compound)은 선택식물과 모든 관속식물에 널리 분포하는 2 차 대사산물로 잎, 줄기, 뿌리, 과실, 종자, 화분 등 식물체 전 부 위에 함유되어있다[4-6]. 태양으로부터 자외선에 피부가 노출 되면 산화적 스트레스의 생성, 염증 매개체의 생성, DNA 손상 및 면역 체계의 억제, 발암 등 피부에 여러 가지 손상을 주고 있 으며 apoptosis에 의해 세포의 죽음으로 유도한다고 보고되었 다. 최근 여러 연구자들의 보고에 의하면 녹차, 폴리페놀류, 포 도씨에서 추출된 proanthocyanidins 등 항산화물질들이 자외 선에 조사된 피부에 부정적인 영향을 미친다는 보고도 있으나, 포도씨에서 추출한 proanthocyanidins의 경우 발암을 억제한 다는 보고도 있고, 포도에서 추출한 폴리페놀 분획이 대장암세 포에서 증식억제효과가 있다는 것을 보고하였다[7]. 캠벨어얼 리 포도가지와 새송이버섯 혼합추출물이 활성화된 면역세포에 서 항염증 및 화학항원과 생물학적 항원을 동시에 처리한 아토 피 피부염 유사 모델 마우스에서 아토피 개선에 대한 상승효과 가 있다고 보고되었다[8]. 또한 resveratrol이 집먼지 진드기로 유도된 아토피 피부염을 약화시킨다는 보고도 있다[9]. Raúl Domínguez-Perles 등은 human keratinocytes에서 포도줄 기 추출물이 산화적 스트레스 감소와 아포토시스를 억제한다는 보고를 하였다[10].

피부건강을 위협하는 요인 중의 하나인 자외선(ultraviolet, UV)은 자연환경에서 쉽게 피부에 직접적으로 노출될 수 있어 이에 대한 관심이 급증하고 있다[11]. 그리고 최근에는 환경오 염으로 인한 오존층의 파괴로 지표에 도달하는 자외선의 양이 많아져 피부질환에 자외선이 미치는 영향에 대한 보고가 증가 되고 있는 추세이다[12]. 자외선에 조사된 세포의 DNA 상해는 세포주기의 정지, DNA 회복 활성, 세포의 죽음과 같은 DNA 상 해 반응을 유발한다[13-15]. DNA 상해 반응이나 유전 독성에 대해 변화를 유발하는 천연물들을 검색하는 일은 항암제나 항 노화제, 자외선 보호제 등의 개발과 관련하여 중요한 의미를 갖 는다[16,17].

본 연구는 선행연구에서 보고된 포도의 품종별, 부위별 유효 성분 분석 및 효능 효과가 활발히 연구되어 있고, 포도의 부위 중
포도전정가지에 폴리페놀 함량도 높은 것으로 보고되고 있다 [18]. 하지만 포도 수확 후 버려지는 포도전정가지 부산물에서 추출된 폴리페놀류의 활용에 대한 연구는 미비한 상태이므로 본 연구는 GPSE (grape pruning stem extract)가 UVB 자외선 조사로 유도된 HR-1 hairless mice에서 피부증식억제, 항알레 르기, 아포토시스 억제효과를 바탕으로 포도전정가지(GPSE) 가 고부가가치를 높일 수 있는 기능성화장품 원료로서의 적용 가능성을 연구하고자 한다.

\section{재료 및 방법}

\section{1. 추출 및 분획}

본 연구에 사용된 포도전정가지는 경상북도 경산시 오봉지 길 일대에서 재배된 켐벨얼리의 전정가지를 사용하였다. 포도 전정가지 $1 \mathrm{~kg}$ 에 $80 \%$ 에탄올을 첨가하여 $60^{\circ} \mathrm{C}$ 에서 90 분 동안 추출한 후 추출액을 No. 2 filter paper로 여과하였다. 여과액을 진공회전농축기를 사용하여 농축하고, 동결 건조한 후 실험에 사용하였다[18].

\section{HPLC (High Performance Liquid Chromatography)를 이용한 포도전정가지 추출물의 성분 분석}

분석에 사용된 표준물질인 procyanidin $\mathrm{B} 3$, rutin, quercetin, kaempferol 은 Sigma Aldrich (St. Louis, MO, USA)로부터 구 입하여 사용하였다. 각 표준물질의 순도는 $99.0 \%$ 이상이었다. HPLC 분석을 위한 물, acetonitrile 은 J.T. Baker (Phillipsburg, $\mathrm{NJ}$, USA)에서 구입하였으며, formic acid는 특급시약으로 Junsei (Tokyo, Japan)에서 구입하여 사용하였다. 함량분석을 위한 HPLC는 Shimadzu 사의 LC-20A 시리즈(Kyoto, Japan) 를 사용하였으며, 이 시스템은 pump (LC-20AT), on-line degasser (DGU-20A3), column oven (CTO-20A), autosampler (SIL-20AC) 및 PDA detector (SPDM20A) 로 구성되어 있다. 분석 결과는 Shimadzu 사의 software인 LC solution software (Version 1.24)를 이용하여 처리하였다. 성분의 정량 분석은 크 로마토그래피 방법을 이용하여 Shimadzu 사의 LC-20A 시리 즈 HPLC (Shimadzu Corp., Kyoto, Japan)로 분석하였다. 분 석조건으로 column은 Waters Sunfire C18 (250 mm×4.6 $\mathrm{mm}, 5 \mu \mathrm{m})$ 을 사용하였으며 column 온도는 $40^{\circ} \mathrm{C}$, 샘플 주입 량은 $20 \mu \mathrm{L}$, 검출기는 $\mathrm{UV}$ detector를 이용하여 $280 \mathrm{~nm}$ 에서 측 정하였다. 그리고 이동상은 $0.1 \%(\mathrm{v} / \mathrm{v})$ formic acid가 함유된 물(A)과 $0.1 \%(\mathrm{v} / \mathrm{v})$ formic acid가 함유된 acetonitrile (B)을 사 용하여 다음과 같이 기울기 용매조건 ( $2 \%$ B (0 min), $35 \%$ ( 25 
$\min$ ), 100\% B (40 min), 5\% B (45.10 min), 5\% B (50 min))으 로 흘려주었으며 유속은 $1.0 \mathrm{~mL} / \mathrm{min}$ 로 진행하였다.

\section{3. 실험동물}

실험동물은 7주령의 암컷 HR/ICR Albino hairless (Hosino Laboratory Animal; Japan SLC, Shizuoka. Japan)을 중앙실 험 동물로부터 구입하였으며, 1 주간 사육실 환경에 적응시킨 후 체중 약 $32 \mathrm{~g}$ 의 7 주령 마우스를 실험에 사용하였다. 총 40 마리 의 마우스를 8 개의 실험 군에 각 실험군당 5 마리씩 무작위으로 배치하였으며, polysulfone 케이지에서 사육하였다. 사료와 물 은 자유로이 공급하였다. 사육실은 온도 $22 \pm 1^{\circ} \mathrm{C}$, 상대습도 $50 \pm 5 \%$, 조명주기 12 시간씩, 환기방식 및 회수 10 회 $/ \mathrm{hr}$, 조도 150 300 lux를 유지하였다. 본 실험을 위하여 영남대학교 의 과대학 동물실험윤리위원회에서 승인을 받은 후 실험을 진행하 였다(YUMC-AEC2014-017).

\section{4. 피부 손상회복을 위한 in vivo 용 시료 제조 및 자외선 조사}

피부 손상회복 정도를 측정하기 위해 in vivo 실험에 사용된 GPSE 와의 혼합 사용하는 serum base는 한국 콜마에서 구입하 였다. GPSE를 serum base에 125, 250, 500, 1,000 및 2,000 $\mathrm{mg} / \mathrm{kg}$ 의 농도로 용해시켜 시험물질을 제조하였다. 시험물질 은 $0.2 \mathrm{~mL}$ 를 취하여 주 7회 일정한 양을 등쪽 면에 12주간 도포 하였다. 실험군은 정상군(normal control group, $\mathrm{NC}$ ): 아무런 처치를 하지 않은 군, UVB 대조군(UVB group, UVB): 자외선 조사+serum base 도포군, 양성대조군(UVB+SC): 자외선조사 +suncream (Kolmar, Korea) 도포군, GPSE 도포군(UVB+GPSE): 자외선 조사+GPSE $125,250,500,1,000,2,000 \mathrm{mg} / \mathrm{kg}$ 도포 군의 총 8 개 실험 군으로 하였다. UVB 조사는 광원으로 UVB lamp GL20SE (Sankyo denki, Japan)를 이용하여 제작한 UVB 조사기를 사용하였으며 광량은 Solarmeter (Solartech, USA) 로 측정하였다. 자외선 조사용 cage를 이용하여 실험동물의 등
부위에 균등하게 초기 1 주부터 3 주까지는 $60 \mathrm{~mJ} / \mathrm{cm}^{2}, 4$ 주부터 6 주까지는 $90 \mathrm{~mJ} / \mathrm{cm}^{2}$, 7 주부터 12 주까지는 $120 \mathrm{~mJ} / \mathrm{cm}^{2}$ 의 광 량으로 격일 간격으로 1 주일에 3 회, 12 주 동안 조사하였다 (Figure 1).

\section{Toluidine blue stain}

항알레르기 효과를 보기위해 GPSE가 도포 후 UVB에 조사된 albino mice를 도살, 피부를 10\% 포르말린에 24시간 고정하였 다. 조직을 절취하여 자동침투기에서 파라핀을 침투 시킨 후 포 매, $4 \mu \mathrm{m}$ 두께로 절편제작 후 $60^{\circ} \mathrm{C}$ 에서 배양한 후 탈파라핀, 함 수과정을 거쳐 mast cell의 정량적인 평가를 위해 toluidine blue pH 0.5용액에 90분 염색 후 수세, 탈수, 투명, 봉입하였다. DP71 microscope digital camera (Olympus, Japan)를 사용, 이미지를 획득한 후 Leopard (Zootos, Korea) 프로그램을 사 용, mast cell의 수를 측정하였다.

\section{6. 면역조직화학적 염색}

표피증식억제 효과를 보기위해 GPSE가 도포 후 UVB에 조사 된 albino mice를 도살, 피부를 10\% 포르말린에 24시간 고정하 였다. 조직을 절취하여 자동침투기에서 파라핀을 침투 시킨 후 포매, $4 \mu \mathrm{m}$ 두께로 절편제작 후 $60^{\circ} \mathrm{C}$ 에서 배양한 후 탈파라핀, 함수과정을 거쳐 UVB에 대한 피부장벽의 염증 회복의 정도를 정량적인 평가를 위해 anti-Mouse PCNA (dilution ratio 1:50, Dako, Denmark) 항체를 사용, 면역조직화학적 염색을 시행하 였다. 조직절편을 탈파라핀 후 함수과정을 거쳐 내인성과산화 효소를 제거하기 위하여 $3 \% \mathrm{H}_{2} \mathrm{O}_{2}$-methanol을 10 분간 처리하 였고, 수세 후 포르말린에 의해 감추어진 항원결합부위인 epitope site를 부활시키기 위해 citric acid buffer pH 6.0 용액 에 슬라이드를 넣고 $120^{\circ} \mathrm{C} 10$ 분간 autoclave 한 후 실온에 20 분간 식히고 수세, $\mathrm{PCNA}$ 항체를 60 분간 반응시킨 후 $\mathrm{TBS}$ buffer에 5분간 3회 수세, 2차 항체인 Dako EnVision+HRP

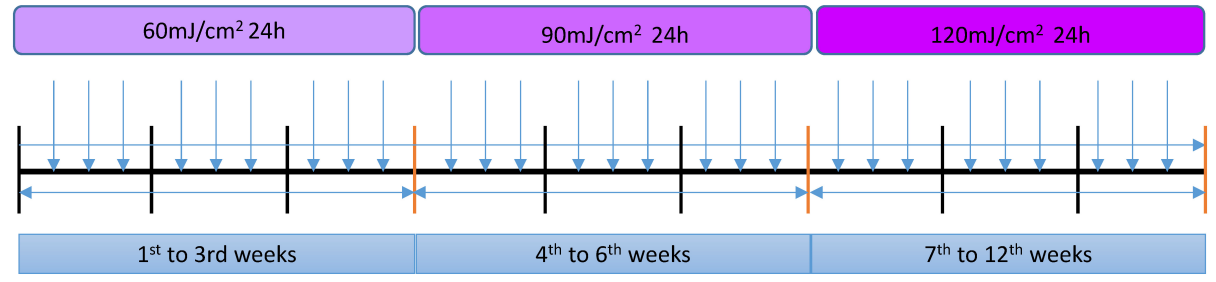

Figure 1. UVB irradiation schedule for $\mathrm{HR}-1$ hairless mice. 
detection system kit를 사용 30분간 반응시킨 후 TBS buffer 에 5분간 3회 수세, $\mathrm{DAB}$ (3,3'-diaminobenzidine)로 5분 발색 시킨 후 Mayer hematoxylin으로 대조염색을 하여 수세, 탈수, 투명, 봉입하였다. DP71 microscope digital camera (Olympus, Japan)를 사용, 이미지를 획득한 후 Leopard (Zootos, Korea) 프로그램을 사용, $\mathrm{PCNA}$ 정량분석 하였다.

\section{TUNEL assay}

Apoptosis를 보기위해 GPSE가 도포 후 UVB에 조사된 albino mice를 도살, 피부를 10\% 포르말린에 24시간 고정하였 다. 조직을 절취하여 자동침투기에서 파라핀을 침투 시킨 후 포 매, $4 \mu \mathrm{m}$ 두께로 절편제작 후 $60^{\circ} \mathrm{C}$ 에서 배양한 후 탈파라핀, 함 수과정을 거쳐 UVB에 대한 GPSE의 anti-apoptosis의 정도를 정량적인 평가를 위해 apoptosis detection kit (millipore, USA)를 사용하여 protein digestion enzyme인 proteinase-K 를 10 분간 처리 후, 수세, 내인성과산화효소를 차단하기 위해 $3 \% \mathrm{H}_{2} \mathrm{O}_{2}$ 를 10 분 처리, equilibration buffer를 15 초간 처리, working strength $\mathrm{TdT}$ enzyme을 $37^{\circ} \mathrm{C} 1$ 시간 반응시킨 후 stop wash buffer에서 15초간 반응정지한 후 anti-digoxigenin conjugate를 처리, $\mathrm{PBS}$ 에 수세, $\mathrm{DAB}$ (3,3'-diaminobenzidine)로 발색, Mayer hematoxylin으로 대조염색, 수세, 탈수, 투명, 봉 입하였다. DP71 microscope digital camera (Olympus, Japan)를 사용, 이미지를 획득한 후 immunoratio 프로그램 (http://153.1.200.58:8080/immunoratio/)을 사용, apoptosis 의 정도를 분석하였다.

\section{8. 통계학적 분석}

본 연구에서 결과는 평균과 표준편차로 나타내었으며, 유의 성 검사는 SPSS version 20.0 통계프로그램(IBM, Armonk, $\mathrm{NY}, \mathrm{USA})$ 으로 one-way ANOVA 를 실시하였고, 대조군 UVB control과 GPSE 도포군 간의 유의성을 Tukey's multiple comparison test로 검증하였다. $p<0.05$ 이상일 때만 유의성 이 있는 것으로 판단하였다.

\section{결 과}

\section{1. 포도전정가지의 추출 수율분석}

포도전정가지의 유효성분 추출은 시료 $53 \mathrm{~kg}$ 을 전달하여 최 종 포도전정가지 추출물을 $2.342 \mathrm{~kg}$ 을 추출하였으며, $4.42 \%$ 수율 결과를 얻었다.

\section{2. 포도전정가지 추출물의 성분 분석결과}

포도가지의 주요성분에 대한 함량분석을 위한 검량선은 상 관계수(r)를 구하여 직선성을 판단하였으며, 4 종 성분에 대한 검량선 작성 결과 상관 계수(r) 값이 0.9998 이상으로 1.0 에 가 까운 양호한 직선성을 나타내었다. 검액에서의 피크 확인은 표 준물질의 피크머무름 시간과 UV 흡수 파장을 비교하여 확인하 였다. Procyanidin B3, rutin, quercetin 및 kaempferol 4종의 성분은 22.48 분, 33.57 분, 34.21 분 및 34.73 분에 각각 검출되 었다. 설정된 HPLC PDA 분석법으로 포도가지의 4종 성분에 대 한 함량 분석을 실시한 결과포도전정가지의 유효성분 분석 결 과, rutin (12.81 mg/g)의 함량이 가장 높은 것으로 2017년 보 고한 바 있다[18].

\section{3. 항 알레르기 효과}

$\mathrm{UVB}$ 를 조사한 후 12 주째 생검하여 $10 \%$ 포르말린 고정 후 파 라핀 포매하여 알레르기 반응시 출현하는 비만세포(mast cell) 를 관찰하기 위하여 toluidine blue 염색을 하였다. 결과 UVB를 조사한 대조군 대비 suncream을 도포한 그룹에서 $61 \%$ 로 가장 높은 알레르기 반응을 나타내었고, 포도전정가지 추출물(GPSE)를 도포한 그룹에서는 정상군과 유사한 결과를 나타내어 GPSE와 serum base의 모든 농도에서 알레르기 반응이 없는 것으로 나 타났다 $(p<0.05)$ (Figure 2).

\section{4. 피부증식 억제효과}

포도전정가지추출물(GPSE)과 serum base와 혼합하여 GPSE의 피부증식 억제 효과를 관찰하기 위하여 UVB를 12 주 동안 조사한 후 생검하여 10\% 포르말린 고정 후 파라핀 포매하 여 표피세포의 증식표지자인 PCNA (proliferating cell nuclear antigen)의 면역조직화학적 염색을 시행하였다. 결과 UVB를 조사한 대조군과 비교하였을 때 GPSE와 serum base의 혼합물 농도 $2,000 \mathrm{mg} / \mathrm{kg}, 1,000 \mathrm{mg} / \mathrm{kg}$ 에서 대조군 대비 $50 \%$ 로 표피 상피세포 증식 억제율을 보였고, GPSE와 serum base의 혼합물 의 모든 농도에서 대조군 대비 평균 $42 \%$ 로 표피상피세포 증식 억제 효과를 보여 유의성이 있는 것으로 나타났다 $(p<0.05)$ (Figure 3).

\section{Apoptosis 억제효과}

$\mathrm{UVB}$ 를 조사한 후 12 주째 생검하여 $10 \%$ 포르말린 고정 후 파 라핀 포매, 세포의 자멸사를 관찰하기 위하여 TUNEL assay를 하였다. UVB를 조사한 대조군과 비교한 결과 GPSE와 serum 


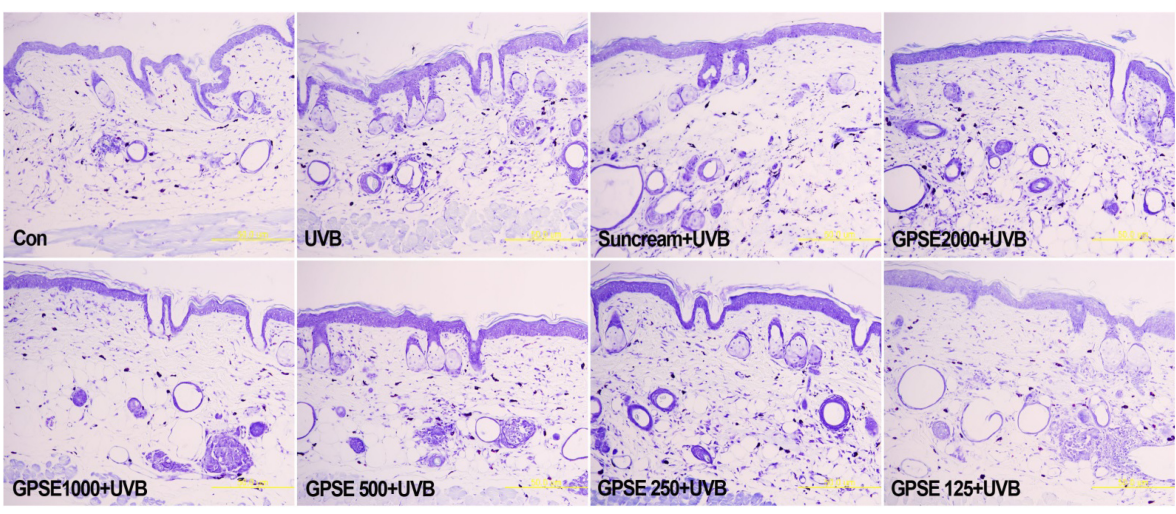

(Toluidine blue stain. X200)
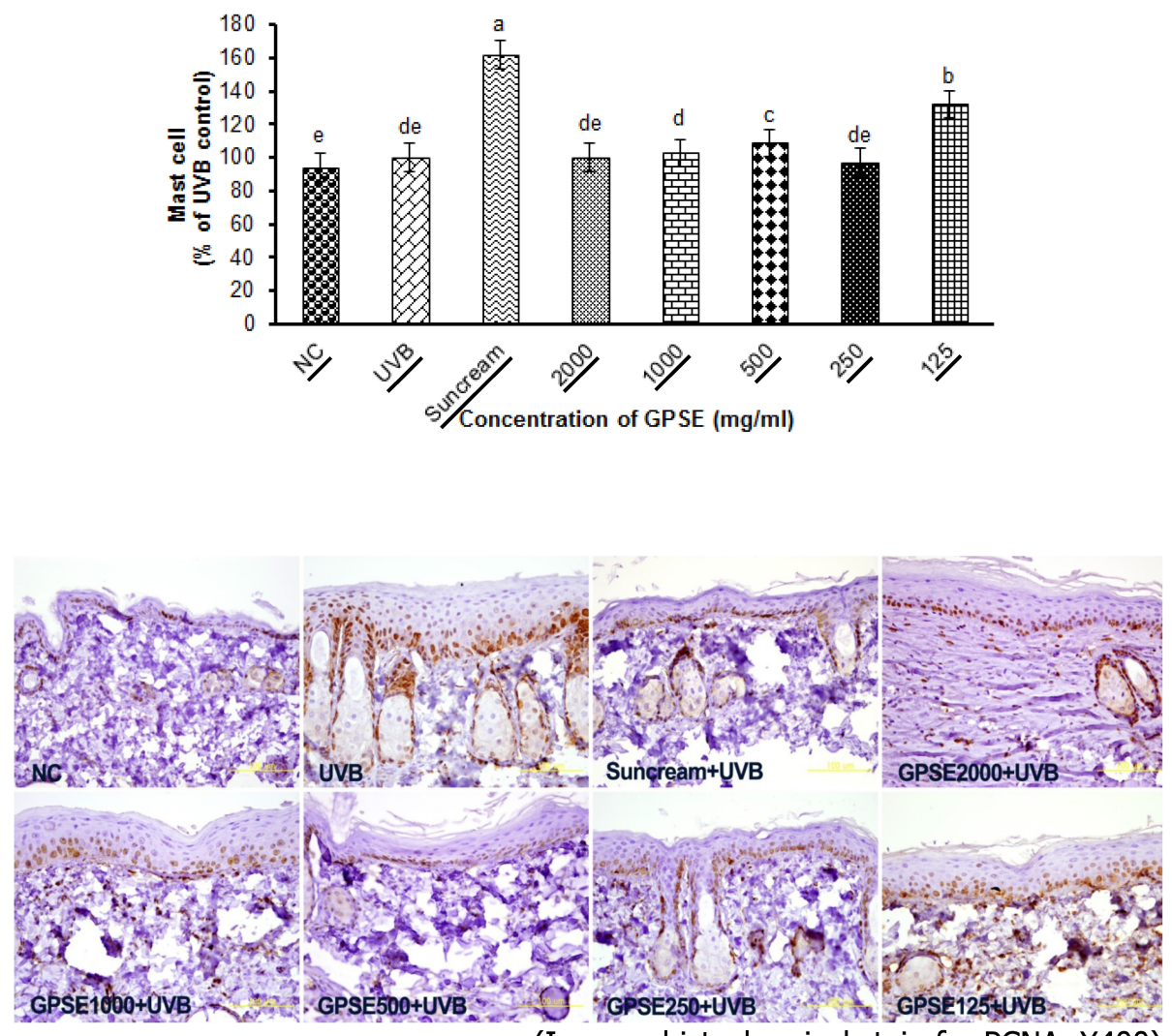

(Immunohistochemical stain for PCNA. X400)

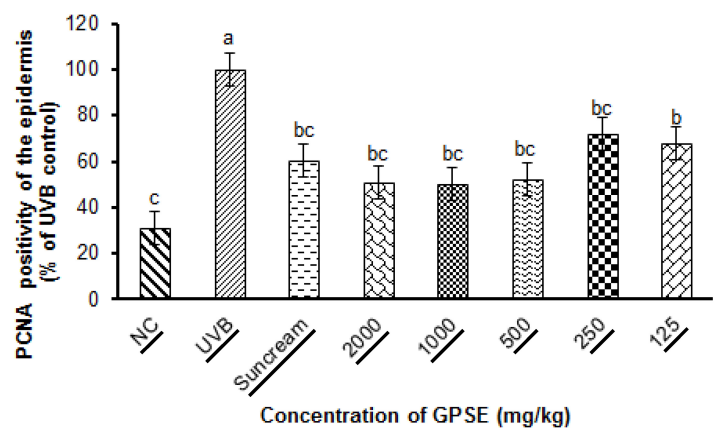

Figure 2. Anti-allergic effect of GPSE in UVB-irradiated $\mathrm{HR}-1$ hairless mice. Skin tissue sections were stained with toluidine blue stain and the images were obtained using an DP71 microscope digital camera $(\times 200)$. Dermis was measured with a Leopard image analyzer and results are expressed as mean $\pm \mathrm{SD}(\mathrm{N}=5)$. Different letters are significantly different at $p$ $<0.05$ by Tukey's multiple comparison test.

Figure 3. GPSE decreases PCNA expression in UVB-irradiated skin of HR-1 hairless mice. Skin tissue sections were stained with PCNA immunohistochemical stain and the images were obtained using an DP71 microscope digital camera $(\times 400)$. Epidermis was measured with a Leopard image analyzer and results are expressed as mean $\pm \mathrm{SD}(\mathrm{N}=5)$. Different letters are significantly different at $p<0.05$ by Tukey's multiple comparison test. 


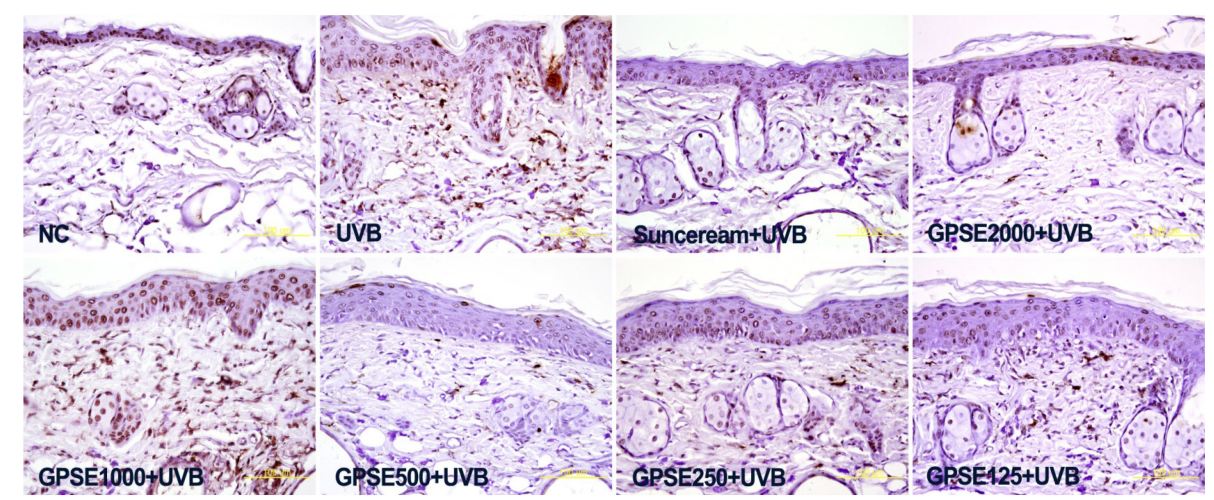

(TUNEL stain. X400)

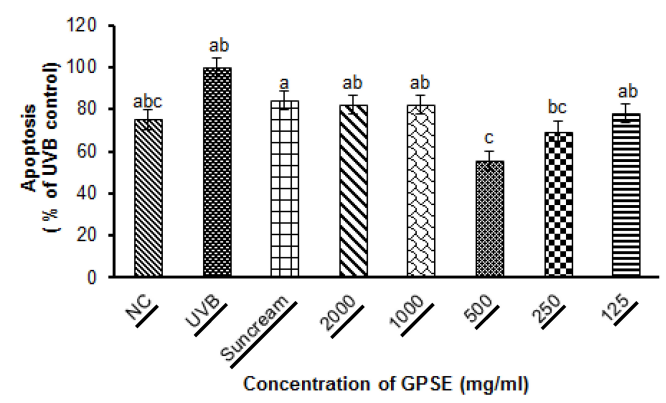

Figure 4. Anti-apoptotic Effect of GPSE in UVB-irradiated HR-1 hairless mice. Skin tissue sections were stained with TUNEL stain and the images were obtained using an DP71 microscope digital camera $(\times 400)$. Epidermis was measured with a immunoratio image analyzer and results are expressed as mean $\pm \mathrm{SD}(\mathrm{N}=5)$. Different letters are significantly different at $p$ $<0.05$ by Tukey's multiple comparison test. base의 혼합물의 모든 농도에서 대조군 대비 평균 $27 \%$ 로 apoptosis 억제 효과가 있었으며, GPSE와 serum base의 혼합 물 농도 $500 \mathrm{mg} / \mathrm{kg}$ 에서 대조군 대비 $45 \%, 250 \mathrm{mg} / \mathrm{kg}$ 에서 $25 \%$ 의 apoptosis 억제율을 보였으며 통계학적 유의성이 있는 것으로 나타났다 $(p<0.05)$ (Figure 4).

\section{고 찰}

본 연구는 경산지역 포도농가에서 포도 수확 후 버려지는 포 도전정가지에서 폴리페놀류와 같은 항산화 물질을 추출하여 유 효성분을 분석하고 UVB로 유도된 피부손상에 대한 피부증식 억제, 항 알레르기, 항염증효과를 증명하고자 in vivo 실험을 하 였다. 선행연구에서는 포도 부위별 폴리페놀류 함량이 품종과 부위에 따라 차이가 있다고 보고하였고, 과피에서는 캠밸얼리 $(0.26 \mathrm{mg} / \mathrm{g})$ 와 흑보석 $(0.61 \mathrm{mg} / \mathrm{g})$ 품종에서만 검출되었으며, 포도전정가지에서는 $\mathrm{MBA}$ 품종 $(1.76 \mathrm{mg} / \mathrm{g})$ 에서 가장 높은 catechin 함량이 있다고 보고된 바 있다[2]. 본 연구자의 선행 보고에서는 포도전정가지의 유효성분 분석 결과, rutin (12.81 $\mathrm{mg} / \mathrm{g}$ )의 함량이 가장 높은 것으로 보고되었다[18]. 이는 포도 나무 품종과 부위에 따라 차이가 있음을 확인하였다. 포도나무 어린가지로부터 resveratrol, viniferin 등의 페놀성 화합물이 항산화효과[19], 항염증효과, 항암효과 등 기능성 식품, 화장품
등의 원료로서의 활용성이 높다고 보고된 바 있다[20]. Matito 등은 포도에서 추출한 폴리페놀 분획이 대장암세포에서 증식억 제효과가 있다는 것을 보고하였다[7]. 본 연구 결과에서도 UVB 조사에 의한 피부증식이 유도된 mouse에서도 피부증식을 억 제하는 결과를 도출하였다(Figure 3). 또한 Karuppagounder 등이 보고한 resveratrol이 집먼지 진드기로 유도된 아토피 피 부염을 약화시킨다는 보고가 있었으나[9], 본 연구에서도 GPSE 가 UVB로 유도된 비만세포의 수를 감소시키는 결과를 얻을 수 있 었다(Figure 2). Domínguez-Perles 등이 2016년에 보고된 바에 의하면 human keratinocyte에서 포도줄기 추출물이 산화적 스트레스를 예방하고 아포토시스를 억제한다고 하였다[10]. 본 연구 결과 in vivo 에서도 역시 GPSE가 아포토시스를 억제하는 결과를 얻었다. 이상의 결과로 포도전정가지로부터 rutin, kaempferol, quercetin, procyanidin B3 등의 페놀성 화합물이 화장품 기초 원료인 serum base에 함유토록 제조된 GPSE는 피부증식 억제, 알레르기 억제, 아포토시스 억제효과를 얻을 수 있었다. 본 연구의 의의는 지역포도농가에서 수확 후 버려지는 포도전 정가지에서 폴리페놀류와같은 유효성분을 확보하여 고부가가 치를 창출할 수 있는 알레르기성 피부용 연고, 기능성화장품 원 료로서의 활용 가치가 높을 것으로 기대된다. 


\section{요 약}

본 연구는 포도수확 후 버려지는 가지를 이용한 포도전정가 지 추출물(grape pruning stem extracts, GPSE)에 함유된 polyphenol류가 UVB로 유도된 HR-1 hairless mice의 손상된 피부에 대한 피부증식 억제, 항 알레르기, 아포토시스 억제능을 분석하여 기능성 화장품 소재로서의 응용 가능성을 확인하고자 하였다. 포도전정가지에서 polyphenol 성분을 $80 \%$ 에탄올로 추출하고 여과하여 농축한 후, 동결건조하여 $-20^{\circ} \mathrm{C}$ 에 보관하 면서 사용하였다. GPSE의 유효성분 함량은 HPLC를 사용하여 선행연구논문에 보고하였다. 피부손상을 유도하기 위해 UVB 를 HR-1 hairless mice에 조사하였고, GPSE가 피부 알레르기 반응을 일으키는지 확인하기 위하여 toluidine blue 염색을 통 하여 비만세포의 수를 확인한 결과 포도전정가지 추출물 (GPSE)를 도포한 그룹에서는 정상군과 유사한 결과를 나타내 어 GPSE 도포군은 알레르기 반응이 없으며 suncream 대조군 대비 현저하게 감소하는 것을 확인할 수 있었다. 표피의 증식표 지자인 PCNA 면역조직화학적 염색을 시행한 결과 GPSE와 serum base 혼합물의 모든 농도에서 대조군 대비 평균 $42 \%$ 로 표피상피세포 증식 억제 효과를 나타내었다. 또한 GPSE와 serum base 혼합물이 자외선 조사로 인한 아포토시스 억제율 은 대조군 대비 평균 $27 \%$ 억제 한다는 것을 알 수 있었다. 이상 의 결과로 포도전정가지로부터 추출한 페놀성 화합물이 화장품 기초 원료인 serum base에 함유토록 제조된 GPSE는 피부증식 억제, 알레르기 억제, 아포토시스 억제효과를 얻을 수 있었다. 본 연구의 의의는 지역포도농가에서 수확 후 버려지는 포도전 정가지에서 폴리페놀류와 같은 유효성분을 확보하여 고부가가 치를 창출할 수 있는 기능성화장품 원료로서의 활용 가치가 높 을 것으로 기대된다.

Acknowledgements: This research was supported by the technological innovation projects of Small-and-Medium Enterprises (SMEs) of Korea funded by the Small \& Medium Business Administration (No. S2085017).

Funding: None

Conflict of interest: None

\section{REFERENCES}

1. Gruenwald J, Brendler B, et al. PDR for herbal medicines. 3rd ed. Montvale, NJ: Medical Economics Company; 2004.

2. Chang EH, Jeong SM, Park KS, Kim BS. Contents of phenolic compounds and trans-resveratrol in different parts of Korean new grape cultivars. Korean J Food Sci Technol. 2013;45(6): 708-713.

3. Ruggieri L, Cadena E, Martinez-Blanco J. Recovery of organic wastes in the spanish wine industry Technical, economic and environmental analyses of the composting process. J Cleaner Prod. 2009;17(9): 830-838.

4. Filip V, Plockova M, Smidrkal J, Spickova Z, Melzoch K, Schmidt S. Resveratrol and its antioxidant and antimicrobial effectiveness. Food Chem. 2003;83(4):585-593.

5. Lee EJ, Min HY, Park HJ, Chung HJ, Kim SH, Han YN, et al. G2/M cell cycle arrest and induction of apoptosis by a stilbenoid, 3, 4, 5-trime-thyoxyl-4-bromo-cis-stilbene, in human lung cancer cells. J Life Sci. 2004;75(23):2829-2839.

6. Lee HJ, Seo JW, Lee BH, Chung KH, Chi DY. Syntheses and radical scavening activities of resveratrol derivatives. Bioorg Med Chem Lett. 2004;14(2):463-466.

7. Matito C, Agell N, Sanchez-Tena S, Torres JL, Cascante M. Protective effect of structurally diverse grape procyanidin fractions against UV-induced cell damage and death. J Agric Food Chem. 2011;59(9):4489-4495.

8. Yin HH, Cho BO, Lee HS, Chu JI, Jang SL. Synergistic effects of grape branch and Pleurotus eryngii extract combination against inflammation on activated mast cells and atopic dermatitis-like skin lesions in mice. Korean J Food Sci Technol. 2016;12(8):582-589.

9. Karuppagounder V, Arumugam S, Thandavarayan RA, Pitchaimani V, Sreedhar R, Afrin R, et al. Resveratrol attenuates HMGB1 signaling and inflammation in house dust mite-induced atopic dermatitis in mice. Int Immunopharmacol. 2014; 23(2):617-623.

10. Domínguez-Perles R, Guedes A, Queiroz M, Silva AM, Barros A. Oxidative stress prevention and anti-apoptosis activity of grape (Vitis vinifera L.) stems in human keratinocytes. Food Research International. 2016;87:92-102.

11. Kripke ML. Immunological effects of ultraviolet radiation. J Dermatol. 1991;18(8):429-433.

12. Freedberg IM, Eisen AZ, Wolff K, Austen KF, Katz SI, Fitzpatrick TM. Dermatology in gerneral medicine. 5th ed. New York: McGraw-Hil; 1999.

13. Nishiwaki Y, Kobayashi N, Imoto K, Iwamoto T, Yamamoto A, Katsumi S, et al. Trichothiodystrophy fibroblasts are deficient in the repair of ultravioletinduced cyclobutane pyrimidine dimers and (6-4) photoproducts. J Invest Dermatol. 2004;122(2): 526-532.

14. Otoshi E, Yagi T, Mori T, Matsunaga T, Nikaido O, Kim ST, et al. Respective roles of cyclobutane pyrimidine dimers, (6-4) photoproducts, and minor photoproducts in ultraviolet mutagenesis of repair-deficient xeroderma pigmentosum A cells. Cancer Res. 2000;60(6):1729-1735.

15. Zhou BS, Elledge SJ. The DNA damage response: Putting checkpoints in perspective. Nature. 2000;408(12):433-439.

16. Wu $\mathrm{CH}$, Yen GC. Antigentoxic properties of Cassia tea (Cassia tora L.): Mechanism of action and the influence of roasting process. J Life Sci. 2004;76(1):85-101.

17. Yen GC, Chuang DY, Wu CH. Free radicals in foods: Chemistry, nutrition and health effects. Washington: ACS Publications; 
336 Joung-Hee Kim, et al. Grape Pruning Stem Extract (GPSE) Suppresses Allergy and Skin Proliferation Inhibition against UVB I

2002. p201-212.

18. Kim JH, Kim JG, Kim SG, Jeong SI, Jang MJ, Kim KS, et al. Photoprotective effect of grape pruning stem extracts on the UVB induced HR-1 mice skin. J Life Sci. 2017;27(4):383-389.

19. Choi Y, Lee J. Antioxidant and antiproliferative properties of a tocotrienol-rich fraction. Food Chem. 2009;114(4):1386-1390.

20. Furiga C, Lonvaud-Funel A, Badet C. In vitro study of antioxidant capacity and antibacterial activity on oral anaerobes of a grape seed extract. Food Chem. 2009;113(4):1037-1040. 